\title{
KEPEMIMPINAN PENDIDIKAN DAN ESSENTIAL TRAITS
}

\author{
ERMI SOLA \\ Universitas Islam Negeri Alauddin Makassar \\ Email: eminpatta@gmail.com
}

(Article History)

Received October 04, 2020; Revised November 09, 2020; Accepted November 10, 2020

\begin{abstract}
:
In general, leadership is an activity that motivate others to do something. It is clearly stated that leadership is more than just to 'motivate'. It deals with some one's ability to lead, and influence others individually or groups to what the leader wants in order to achieve a desired goal (s). Leadership is important in an organization, include education. Principal's leadership most likely influences the success or failure of the schools. A principal has a big responsibility toward his school management as a whole, such as educational program teaching and learning, administration, guiding the staff, using and maintaining school's infrastructures. Besides, the principal has to optimize his role and educational functions, i.e. leader, motivator, educator, supervisor, administrator, innovator, manager. Those responsibilities can be carried out well if the principal has qualities that makes him a great leader as a leader.
\end{abstract}

Keywords: Leadership, Education, Trait

\section{PENDAHULUAN}

K epemimpinan merupakan bagian penting dalam kajian manajemen. Kepemimpinan berkaitan dengan kapabilitas individu pemimpin dalam mensugesti, memotivasi, mengajak, membina, menggerakkan individu atau kelompok untuk melakukan sesuatu dalam upaya mewujudkan "goals" yang telah ditetapkan. Dalam hubungannya dengan suatu lembaga/insititusi, kegiatan kepemimpinan dengan segenap atributnya pada prinsipnya bermuara pengejawantahan cita-cita yang telah disepakati orang-orang yang terlibat didalamnya. Leadership dalam bidang pendidikan merupakan kemampuan kepala sekolah dalam rangka proses mendorong, memengaruhi, mengkoordinir dan menggerakkan para guru dan anggota persekolahan lainnya terkait dengan penerapan proses belajar dan mengajar dalam usaha mencapai cita-cita pendidikan dan pengajaran yang optimal.

Sekolah merupakan organisasi non profit yang menyediakan jasa layanan bagi users. Kepala sekolah memiliki tugas dan "responsibility" yang melebihi "civitas academica" lainnya. Keberhasilan penyelenggaraan pembelajaran dapat dipastikan berada di pundak kepala sekolah dalam membawahi pendidik dan tenaga kependidikan. Keberadaan kepala sekolah dalam berbagai aktivitas baik dari segi akademik maupun administratif sekolah, sarana-prasarana, dan lingkungan sekitar 
merupakan indikator keberhasilan atau kegagalannya. Komitmen dan support para pemangku kepentingan turut memberi andil bagi kemajuan sekolah. Kualitas kepribadian turut memberikan kontribusi secara signifikan dan turut menentukan keberhasilan atau kegagalan kepala sekolah selaku pemimpin pendidikan di sekolahnya.

\section{HASIL PENELITIAN DAN PEMBAHASAN \\ Defenisi Kepemimpinan Pendidikan}

Istilah leadership atau kepemimpinan sejatinya memiliki sudut pandang yang luas dan beragam, sebagaimana Haris (2013, h. 13) mengatakan "Tidak ada defenisi yang baku mengenai kepemimpinan tersebut". Dalam pengertian yang sangat lugas, Makawimbang (2012, h. 6) mendefenisikan "Kepemimpinan sebagai kapabilitas yang dipunyai oleh individu dengan tujuan membujuk orang lain". Secara praktis, dipahami sebagai kegiatan penataan dalam bentuk kemampuan untuk mempengaruhi tingkah laku orang lain supaya bisa bekerjasama dengan baik dalam situasi tertentu. Kepemimpinan juga diartikan sebagai kepiawaian atasan dalam menjalankan peran kepemimpinannya dengan tujuan agar bawahannya bergerak berdasarkan keputusan yang telah ditetapkan. Orang-orang yang bergerak atau melakukan kegiatan dalam sebuah organisasi harus mengacu kepada tujuan organisasi tersebut. Seorang pemimpin merupakan sosok individu yang dipandang memiliki kelebihan dalam hal kewenangan dan kekuasaan tertentu, menyangkut program jangka pendek maupun jangka panjang (Suryadi, 2010). Educational leadership adalah juga kesanggupan pimpinan dalam menggerakkan orang lain secara sukarela agar tujuan pendidikan dapat dicapai (Soetopo dan Soemanto dalam Nasution, 2015). Lengkapnya, Fatonah (2017, h. 114) mengatakan "Kepemimpinan terkhusus dalam ranah kependidikan dimaknai sebagai kesanggupan seorang individu dalam membimbing, menggerakkan dan mengarahkan anggota atau bawahannya berkenaan dengan implementasi proses pendidikan dan pengajaran dalam rangka mewujudkan tujuan yang telah ditetapkan."

Dari berbagai pengertian dan penjelasan para ahli tersebut, dapat dipahami bahwa leadership pendidikan berkaitan dengan kemahiran atau keahlian seorang pimpinan dalam memengaruhi dan mengerahkan para guru serta semua orang yang berada dalam naungan sekolah, tidak terkecuali warga masyarakat agar secara aktif ikut berpartisipasi melaksanakan dan mengembangkan berbagai kegiatan pendidikan secara optimal dan berkesinambungan demi tercapainya tujuan pendidikan yang diinginkan.

\section{Fungsi Kepemimpinan Pendidikan}

Secara sederhana, Wahjosumidjo (2002, h. 82) mengatakan "Kepala sekolah selaku pimpinan pendidikan berfungsi sebagai manajer, pemimpin, dan pendidik". Lebih detail, Dikutip dalam Depdiknas Dirjen Pendidikan Dasar dan Menengah 
(2000, h. iv) sebagai berikut "Fungsi kepemimpinan pendidikan diklasifikasikan menjadi tujuh, yakni: Educator, Manager, Administrator, Supervisor, Leader, Innovator, dan Motivator (EMASLIM)". Dalam fungsi educator, kepala sekolah menjalankan fungsi kepemimpinannya dalam hal-hal prestasi yang dimiliki para guru, kemampuan dalam membimbing tenaga pendidik, kemampuan dalam membimbing karyawan, membimbing peserta didik, mengembangkan staf, kemampuan dalam belajar serta mengikuti perkembangan ilmu pengetahuan dan teknologi, kemampuan memberi contoh dalam mengajar.

Fungsi manager meliputi kemampuan dalam menyusun program, kemampuan dalam menyusun organisasian kepegawaian, menggerakkan staf, kemampuan dalam mengoptimalkan daya institusi pada lembaga pendidikan yang ditempati.

Fungsi administrator, meliputi kemampuan dalam mengelola segala administrasi yang menyangkut proses belajar mengajar, kemampuan mengelola bimbingan dan konseling, kesiswaan, ketenagaan, keuangan, sarana dan prasarana, mengelola administrasi persuratan.

Fungsi supervisor bermakna kepala sekolah bertindak sebagai manajer. Fungsi leader bermakna kepala sekolah menjalankan tugas dan tanggung jawabnya sebagai inovator dan motivator. Terakhir, fungsi inovator dan motivator, pada fungsi ini kepala sekolah menjalankan tugas dan tanggung jawabnya sebagai leader.

Rohmat (2016) menyederhanakan ketujuh fungsi kepemimpinan pendidikan, menjadi 2 fungsi utama, yaitu manager dan leader. Pertama, Manager mencakup didalamnya fungsi administrator, dan supervisor (penyelia) dengan tugas dan tanggung jawab dalam hal: (1) Planning (perencanaan) mencakup: kemampuan menentukan tujuan organisasi; kemampuan merumuskan program institusi pendidikan; kemampuan menyusun strategi pengembangan; kemampuan menentukan standarisasi pencapaian tujuan. (2) Organizing (pengorganisasian) mencakup: kemampuan menghimpun dan mengkoordinasi SDM; kemampuan menghimpun dan mengkoordinasi sumber-sumber material institusi pendidikan; kemampuan menentukan sumber daya yang dibutuhkan institusi pendidikan; kemampuan menentukan kegiatan yang dibutuhkan untuk mencapai tujuan; kemampuan mengembangkan organisasi atau institusi pendidikan; kemampuan penugasan dan tanggung jawab kepada tenaga pendidik dan staf administrasi. (3) Staffing (penyusunan personalia) mencakup: kemampuan penentuan kebutuhan SDM; kemampuan mengadakan rekruitment; kemampuan mengadakan sampai selesai; kemampuan mengadakan pelatihan dan pengembangan SDM; kemampuan mengadakan orientasi pada tenaga pendidik dan staf administrasi. (4) Leading (pengarahan) mencakup: kemampuan menyusun job description; kemampuan untuk menempatkan para bawahan pada SDM yang tepat; kemampuan untuk membangkitkan semangat kerja; kemampuan untuk memberikan arahan bagi para tenaga pendidik dan staf administrasi. (5) Controlling (pengawasan), mencakup aspek-aspek: kemampuan untuk penilaian kinerja bawahan; kemampuan untuk 
mengidentifikasi kasus-kasus penyimpangan; kemampuan mengadakan strategi untuk mengadakan perubahan; kemampuan menyusun strategi untuk kontrol terhadap proses pencapaian tujuan. Kedua, Leader mencakup di dalamnya fungsi sebagai inovator dan motivator.

Khamdani (2014) mengemukakan fungsi utama pemimpin pendidikan sebagai berikut: (1) Mampu menciptakan suasana kerja sama dan persaudaraan yang baik sehingga pekerjaan yang dijalani terasa mudah; (2) Mampu mengorganisir bawahan sehingga tujuan dapat tercapai; (3) Mampu membuat prosedur kerja untuk kelompok dengan melihat lingkungan sekitar sehingga dapat memilih prosedur yang lebih efektif dan efisien; (3) Bertanggung jawab dalam menangani kasus bersama kelompok dan adil dalam memimpin kelompok.

Seiring dengan yang disampaikan Khamdani, Wahjosumidjo (2002) mengemukakan kepemimpinan pendidikan sebagai berikut: (1) Bertanggung jawab agar para tenaga pendidik, staf administrasi, dan siswa menyadari tujuan institusi pendidikan yang telah ditetapkan; (2) Bertanggung jawab untuk menyediakan segala dukungan, peralatan, fasilitas, berbagai peraturan, dan suasana yang mendukung kegiatan; (3) Memahami motivasi setiap tenaga pendidik, staf administrasi, dan siswa, mengapa mereka bersikap dan berperilaku baik yang bersifat positif maupun reaksi yang tidak mendukung; (4) Sumber inspirasi bawahan; (5) Menjaga keseimbangan antara tenaga pendidik, staf administrasi, dan siswa, serta kepentingan masyarakat pihak lain; (6) Menyadari bahwa esensi kepemimpinan adalah kepengikutan (the followership), artinya kepemimpinan tidak akan terjadi apabila tidak didukung pengikut; (7) Membimbing, mengadakan koordinasi kegiatan, mengadakan pengendalian atau pengawasan, dan pembinaan agar masing-masing anggota atau bawahan memperoleh tugas yang wajar dan proporsional.

\section{Kualitas Kepribadian Pemimpin "Besar”}

Kualitas kepribadian pemimpin yang ideal penting seyogyanya dimilliki oleh seorang pemimpin, tidak terkecuali pemimpin pendidikan. Seorang pemimpin harus mampu bertemu sesering mungkin dengan para anggota organisasi pendidik dan tenaga pendidik lainnya; bahkan jika perlu dengan staf lainnya seperti cleaning service, driver, security, dan canteen. Pertemuan dimaksud tidak harus selalu secara formal coffee morning, tapi dapat melalui percakapan ringan "bermakna”. Seorang pemimpin juga harus mampu merangkul anggota atau bawahannya dari semua lini tanpa membedakan fungsi dan posisi masing-masing. Di samping itu, pemimpin juga harus mampu mengarahkan anggota atau bawahannya secara "ing ngarso sung tulodo, ing madyo mangun karso, tut wuri handayani" (Ki hajar Dewantara). Artinya, pemimpin harus mampu mengarahkan, menyemangati, dan mendorong para pendidik, tenaga kependidikan, dan para staf lainnya yang memiliki semangat dan motivasi tinggi dalam bekerja; yang masih belum optimal dalam bekerja, bahkan yang masih malas). Terakhir, seorang pemimpin tidak diharapkan untuk "overconfidence" dalam melakoni kepemimpinannya. Sikap overconfidence dapat 
menjerumuskan pemimpin kepada perilaku "lalai/lengah". Lengah dan Ialainya pemimpin karena overconfidence tersebut akan berakibat pada gagalnya rencana yang telah disusun matang dan dapat berujung pada tujuan yang tidak sesuai dengan yang diharapkan/targetkan.

Kualitas kepribadian yang dapat menjadikan seseorang sebagai pemimpin besar dicirikan sebagai berikut, yaitu: fokus pada apa yang dilakukan (focus); memiliki rasa percaya diri yang baik (confidence); transparan pada hal-hal yang memang seharusnya jujur (transparency); memiliki integritas tinggi terhadap komitmen (integrity); dapat menginspirasi bawahan dan atau orang lain (inspiration); memiliki obsesi/keinginan kuat untuk sukses (passion); inovatif (innovative); sabar , (patience); tabah (stoicism); tidak sembrono (wonkiness); otentik/keaslian (authenticity); berpikiran terbuka (open-mindedness); tegas dalam berkeputusan dan bertindak (decisiveness); berkepribadian (personableness); memberdayakan (empowerment); mampu membangun budaya (optimis positivity); murah hati (generosity); gigih, ulet (persistence); memiliki wawasan luas (insightfulness); mampu berkomunikasi dengan baik dengan bawahan dan orang lain (communication); dapat dipertanggungjawabkan (accountability), dan resah ketika bawahan memiliki masalah dan tidak mampu mereka selesaikan (restlessness).

\section{PENUTUP/SIMPULAN}

Kepemimpinan pendidikan pada hakikatnya merupakan kemampuan yang dimiliki oleh seorang individu pemimpin sebagai penanggung jawab dalam ranah penyelenggaraan pendidikan dan pengajaran. Pemimpin berkewajiban mendorong, membimbing, dan menggerakkan bawahan pendidik dan tenaga kependidikan serta warga sekolah lainnya dalam rangka mencapai tujuan yang sudah ditetapkan bersama. Kepala sekolah sebagai pemimpin bertanggung jawab melaksanakan fungsi-fungsi kepemimpinannya sebagai educator, manager, administrator, supervisor, leader, inovator, dan motivator. Keseluruhan fungsi kepemimpinan kepala sekolah tidak akan terwujud dengan sempurna jika tidak diiringi dengan kualitas kepribadian yang baik. Kepribadian yang dimaksud adalah focus, confidence, transparency, integrity, inspiration, passion, innovative, patience, stoicism, wonkiness, authenticity, open-mindedness, decisiveness, personableness, empowerment, positivity, generosity, persistence, insightfulness, communication, accountability, dan restlessness.

\section{DAFTAR PUSTAKA}

Depdiknas Dirjen Pendidikan Dasar dan Menengah. (2000). Rambu-rambu Penilaian Kinerja Institusi Pendidikan (SLTP dan SMU). Jakarta: Rineka Cipta.

Fatonah, I. (2017). Kepemimpinan Pendidikan. Tarbawiyah: Jurnal IImiah Pendidikan, 10(02), 109-125. 
Haris, A. (2013). Kepemimpinan Pendidikan. Surabaya: Islamic Development Bank. Khamdani, P. (2014). Kepemimpinan dan Pendidikan Islam. Jurnal Madaniyah, VII, 259-276.

Makawimbang, J. H. (2012). Kepemimpinan Pendidikan yang Bermutu. Bandung: Alfa Beta.

Nasution, W. N. (2015). Kepemimpinan Pendidikan di Sekolah. Jurnal Tarbiyah, 22(1), 66-86.

Rohmat. (2016). Kepemimpinan Pendidikan. Jurnal Pemikiran Alternatif Pendidikan, 11(1), 1-11.

Suryadi, A. (2010). Kepemimpinan Pendidikan. Retrieved from http://file.upi.edu/Direktori/FIP/Jur. Administrasi Pendidikan/197203211999031ASep_Suryana/CopyofDiktetkepemimpinan pendidikan1.pdf

Wahjosumidjo. (2002). Kepemimpinan Kepala Sekolah: Tinjauan Teoretis dan Permasalahannya. Jakarta: Raja Grafindo Persada. 